Article

\title{
An At-Risk Population Screening Program for Mucopolysaccharidoses by Measuring Urinary Glycosaminoglycans in Taiwan
}

\author{
Hsiang-Yu Lin ${ }^{1,2,3,4,5,6}{ }^{\mathbb{D}}$, Chung-Lin Lee ${ }^{7,8}$, Yun-Ting Lo ${ }^{9}$, Ru-Yi Tu ${ }^{3}$, Ya-Hui Chang ${ }^{2}$, \\ Chia-Ying Chang ${ }^{7}$, Pao Chin Chiu ${ }^{10}$, Tung-Ming Chang ${ }^{11,12}$, Wen-Hui Tsai ${ }^{13}$, \\ Dau-Ming Niu ${ }^{8,14}$, Chih-Kuang Chuang ${ }^{3,15, *}$ and Shuan-Pei Lin 1,2,3,16,*
}

1 Department of Medicine, MacKay Medical College, New Taipei City 252, Taiwan; 1xc46199@ms37.hinet.net

2 Department of Pediatrics, MacKay Memorial Hospital, Taipei 100, Taiwan; wish1001026@gmail.com

3 Department of Medical Research, MacKay Memorial Hospital, Taipei 100, Taiwan; likemaruko@hotmail.com

4 MacKay Junior College of Medicine, Nursing and Management, Taipei 100, Taiwan

5 Department of Medical Research, China Medical University Hospital, China Medical University, Taichung 400, Taiwan

6 Institute of Biomedical Sciences, MacKay Medical College, New Taipei City 252, Taiwan

7 Department of Pediatrics, MacKay Memorial Hospital, Hsinchu 300, Taiwan; clampcage@yahoo.com.tw (C.-L.L.); a4964@ms7.mmh.org.tw (C.-Y.C.)

8 Institute of Clinical Medicine, National Yang-Ming University, Taipei 100, Taiwan; dmniu1111@yahoo.com.tw

9 Department of Laboratory Medicine, MacKay Memorial Hospital, Taipei 100, Taiwan; andy11tw.e347@mmh.org.tw

10 Department of Pediatrics, Kaohsiung Veterans General Hospital, Kaohsiung 800, Taiwan; pcchiu@vghks.gov.tw

11 Department of Pediatric Neurology, Changhua Christian Children's Hospital, Changhua 500, Taiwan; 128658@cch.org.tw

12 Department of Biological Science and Technology, College of Biological Science and Technology, National Chiao Tung University, Hsinchu 300, Taiwan

13 Department of Pediatrics, Chi Mei Medical Center, Tainan 700, Taiwan; whys.tsai@gmail.com

14 Department of Pediatrics, Taipei Veterans General Hospital, Taipei 100, Taiwan

15 College of Medicine, Fu-Jen Catholic University, Taipei 100, Taiwan

16 Department of Infant and Child Care, National Taipei University of Nursing and Health Sciences, Taipei 100, Taiwan

* Correspondence: mmhcck@gmail.com (C.-K.C.); linhy@mmh.org.tw (S.-P.L.); Tel.: +886-2-28094661 (ext. 2348) (C.-K.C.); +886-2-2543-3535 (ext. 3090) (S.-P.L.); Fax: +886-2-2808-5952 (C.-K.C.); +886-2-2543-3642 (S.-P.L.)

Received: 16 September 2019; Accepted: 2 October 2019; Published: 5 October 2019

Abstract: Background: The mucopolysaccharidoses (MPSs) are a group of rare lysosomal storage disorders characterized by the accumulation of glycosaminoglycans (GAGs) and which eventually cause progressive damage to various tissues and organs. We developed a feasible MPS screening algorithm and established a cross-specialty collaboration platform between medical geneticists and other medical specialists based on at-risk criteria to allow for an earlier confirmative diagnosis of MPS. Methods: Children ( $<19$ years of age) with clinical signs and symptoms compatible with MPS were prospectively enrolled from pediatric clinics between July 2013 and June 2018. Urine samples were collected for a non-specific total GAG analysis using the dimethylmethylene blue (DMB) spectrophotometric method, and the quantitation of three urinary GAGs (dermatan sulfate (DS), heparan sulfate (HS), and keratan sulfate (KS)) was performed by liquid chromatography/tandem mass spectrometry (LC-MS/MS). The subjects with elevated urinary GAG levels were recalled for leukocyte enzyme activity assay and genetic testing for confirmation. Results: Among 153 subjects enrolled in this study, 13 had a confirmative diagnosis of MPS (age range, 0.6 to 10.9 years-three 
with MPS I, four with MPS II, five with MPS IIIB, and one with MPS IVA). The major signs and symptoms with regards to different systems recorded by pediatricians at the time of the decision to test for MPS were the musculoskeletal system (55\%), followed by the neurological system (45\%) and coarse facial features (39\%). For these 13 patients, the median age at the diagnosis of MPS was 2.9 years. The false negative rate of urinary DMB ratio using the dye-based method for these 13 patients was 31\%, including one MPS I, two MPS IIIB, and one MPS IVA. However, there were no false negative results with urinary DS, HS and KS using the MS/MS-based method. Conclusions: We established an at-risk population screening program for MPS by measuring urinary GAG fractionation biomarkers using the LC-MS/MS method. The program included medical geneticists and other medical specialists to increase awareness and enable an early diagnosis by detecting MPS at the initial onset of clinical symptoms.

Keywords: cross-specialty collaboration; glycosaminoglycans; high-risk screening; liquid chromatography/tandem mass spectrometry; mucopolysaccharidosis

\section{Introduction}

The mucopolysaccharidoses (MPSs) are a group of rare lysosomal storage disorders caused by the deficiency of specific enzymes that catalyze the stepwise degradation of glycosaminoglycans (GAGs). Currently, 11 enzymes are known to be involved in the catabolism of dermatan sulfate (DS), heparan sulfate (HS), keratan sulfate (KS), chondroitin sulfate (CS), and hyaluronic acid. Specific enzyme deficiency leads to the accumulation of GAGs in cells and eventually causes progressive damage to various tissues and organs [1]. The clinical presentations of MPS include coarse facial features, developmental delay, corneal clouding, adenotonsillar hypertrophy, hearing loss, upper airway obstruction, pulmonary function impairment, obstructive sleep apnea, cardiovascular disease, hepatosplenomegaly, short stature, joint stiffness, and skeletal deformities (dysostosis multiplex). The clinical signs and symptoms in these patients are chronic and progressive, and may present from early to late childhood or even in early adulthood, and the severity and prognosis vary among different types with a wide spectrum of clinical severity [2-10]. All types of MPS exhibit autosomal recessive inheritance except MPS II (Hunter syndrome), which is transmitted in an X-linked recessive mode and thus predominantly affects males. The incidence of MPS in different populations ranges from 1.9 to 4.5 per 100,000 live births. In Taiwan, this has been estimated to be 2.04 per 100,000 live births [11].

A precise diagnosis of MPS disorders is traditionally made through three consecutive analyses: the quantification of urinary GAGs, two-dimensional electrophoresis (2-D EP) qualitative examination, and leukocyte enzyme activity assay [12,13]. Urinary GAG quantitative tests can be used as a diagnostic screening device for MPS; however, they cannot be used to determine a specific MPS type. The dimethylmethylene blue (DMB) spectrophotometry method is broadly used in most biochemical genetics laboratories; however, it involves a non-specific total GAG assay which can cause both false positive and false negative results, especially in patients with MPS III and IV [13,14]. Two-dimensional EP is the most commonly used method to identify specific types of MPS; however, it is laborious, and its interpretation is subjective and ambiguous, making the diagnosis unreliable. To resolve the limitations of these first-line screening methods for MPS, the liquid chromatography/tandem mass spectrometry (LC-MS/MS) method has been used to identify MPS subgroups, and it has been shown to be an accurate and reliable method [15-18].

The major therapies for MPS disorders include enzyme replacement therapy (ERT) and hematopoietic stem cell transplantation (HSCT). ERT is now available for MPS I, II, IVA, VI, and VII, and it has been demonstrated to remarkably reduce urinary GAG levels and substantially improve endurance, joint mobility, physiological activities, and quality of life [19-28]. HSCT is currently the only treatment to prevent progressive neurodegenerative disorders in MPS I, II, VI, and VII [29]. Some 
developing therapeutics for MPS disorders are currently in clinical trials, including substrate reduction therapy, chaperone therapy, and gene therapy $[30,31]$. Previous studies have indicated that early treatment may contribute to a better clinical outcome [32-34].

Since MPS disorders are rare, multisystemic and progressive diseases with subtle signs and symptoms at the beginning of the natural course, making an early diagnosis can be a challenge for first-line health care professionals. Tracing back the medical history, the patients are usually brought to miscellaneous medical specialists due to diverse manifestations before the confirmative diagnosis of MPS [35-37]. In Taiwan, there is insufficient awareness of MPS, which can lead to a delay in the diagnosis or even misdiagnosis with other disorders, and thus these patients often receive inappropriate management. Identifying and understanding the early signs and symptoms of this disease may allow for an early diagnosis and timely appropriate treatment [38-41]. Therefore, the purpose of this study was to develop a feasible MPS screening algorithm and establish a cross-specialty collaboration platform between medical geneticists and other medical specialists based on at-risk criteria by measuring urinary GAG fractionation biomarkers using the LC-MS/MS method to allow for an earlier confirmative diagnosis of MPS.

\section{Materials and Methods}

\subsection{Study Population}

Children ( $<19$ years of age) with clinical signs and symptoms raising the suspicion of MPS were prospectively enrolled between July 2013 and June 2018 from the pediatric clinics of six medical centers in Taiwan, including Taipei MacKay Memorial Hospital, Hsinchu MacKay Memorial Hospital, Kaohsiung Veterans General Hospital, Taipei Veterans General Hospital, Chi Mei Medical Center, and Changhua Christian Children's Hospital. The health care professionals were asked to record the clinical signs and symptoms that raised the suspicion of MPS when they sent the urine samples to our laboratory (Table 1). Urine samples were randomly collected in sterile plastic urine containers (polyethylene; Nalge Nunc International, USA) with screw caps and stored in a refrigerator at $4{ }^{\circ} \mathrm{C}$ one night before urinary biochemistry analysis or stored in freezer at $-20^{\circ} \mathrm{C}$ for long-term storage. Urine creatinine was measured using an enzymatic method (Beckman DXC-880i) at the Department of Clinical Laboratory Medicine, MacKay Memorial Hospital.

\subsubsection{Ethics Approval and Consent to Participate}

All procedures followed were in accordance with the ethical standards of the responsible committee on human experimentation (institutional and national) and with the Declaration of Helsinki of 1975, as revised in 2000. The Institutional Review Board of MacKay Memorial Hospital approved this study, and written informed consent was obtained from all of the patients or their parents who were included in the study.

\subsubsection{Consent for Publication}

Written informed consent for publication was obtained from all of the patients or their parents who were included in the study.

\subsection{First-Line Biochemistry Examinations and the Confirmative Methods}

\subsubsection{DMB Method}

In this study, non-specific total GAG analysis was applied using the dye-based spectrophotometry method reported by de Jong J.D. et al. [42,43]. GAGs are determined quantitatively in urine by reaction with the dye dimethylmethylene blue (DMB) in a reaction, and the colour is measured rapidly at a wavelength of $520 \mathrm{~nm}$. The $\mathrm{DMB} /$ creatinine ratio, which gives an estimation of the GAG concentration in urine, is age-dependent, and thus the $\mathrm{DMB} /$ creatinine ratio can be used as an MPS referential 
diagnosis but cannot be used for MPS type determination. The higher DMB/creatinine ratio comes mostly from the very young group (infants less than 2 years old); on the contrary, the DMB/creatinine ratio is lower and nearly constant in the adult group (older than 18 years old).

\subsubsection{2-D EP Method}

The GAG disaccharide pattern was determined by 2-D EP according to the method proposed by Hopwood et al. [44] and the protocol issued by Willink Biochemical Genetics Unit, Royal Manchester Children Hospital, Pendlebury, Manchester, UK. The 2-D EP method is reliable and specific and can provide a very good separation of GAG components. Two-dimensional EP is the most common and feasible method used for MPS type determination, which is the basis of MPS confirmation.

\subsubsection{LC-MS/MS of DS, HS, and KS}

The urine quantification of three GAG-derived disaccharides (dermatan sulfate (DS), heparan sulfate (HS), and keratan sulfate (KS)) was performed using the MS/MS-based method. In our study, the principles of methanolysis (chemical hydrolysis) $[16,17,45]$ and keratanase II (specific enzymatic digestion) [46-48] were applied separately for the quantification of individual GAG-derived disaccharides including DS and HS, as well as KS by tandem mass spectrometry assay, respectively. The validation accuracy of the MS/MS-based method which we applied was good in that the accuracy (\%) of this method was $101.1( \pm 6.4), 103.3( \pm 8.1)$, and $103.9( \pm 8.3)$ for DS, HS, and KS, respectively. The intra- and inter-assay precisions (coefficient of variation; CV (\%)) were excellent, as the CV (\%) values of individual DS, HS, and KS were all less than $10 \%$. The recoveries of this LC-MS/MS assay were $94.3 \%$ for DS, $95.1 \%$ for HS, and $94.2 \%$ for KS. In addition, the linearity of DS (ranging from 12.5 to $200 \mu \mathrm{g} / \mathrm{mL}$ ), HS (ranging from 3.125 to $50 \mu \mathrm{g} / \mathrm{mL}$ ), and KS (ranging from 31.25 to $1000 \mu \mathrm{g} / \mathrm{mL}$ ) was calculated individually, and the correlation coefficients (r) were $0.9972,0.9969$, and 0.9992, respectively. Based on the results detected by the LC-MS/MS method, the quantities of the affected GAGs are distinctive for MPS type determinations. The results fully matched those examined by the 2-D EP method and correspond well with the leukocyte enzyme assay.

As we are aware, KS is either of two glycosaminoglycans (I and II), consisting of repeating disaccharides units of $N$-acetylglucosamine (GlcNAc-6-sulfate) and galactose in the $\beta-1,4$ linkage. KS are present in the cornea, cartilage, and bone. The designations KS I and KS II were originally assigned on the basis of the tissue type from which the keratan sulfates were isolated. KS I was isolated from corneal tissue and KS II from skeletal tissue. According to the conclusion reported by Shimada T. et al., "the level of di-sulfated KS and its ratio to total KS can distinguish control subjects from patients with MPS II, IVA, and IVB, indicating that di-sulfated KS can be a novel biomarker for these disorders." [49]. Thus, uKS should be measured with both mono- and di-sulfated KS levels in urine; however, we have only shown the quantitative values of mono-sulfated KS in urine in this study.

\subsubsection{Enzyme Activity Measurements}

MPS enzyme activity measurements include MPS I ( $\beta$-iduronidase; IDUA) [50,51], II (iduronate2-sulfate sulfatase; IDS) [51,52], IIIB ( $\alpha$ - $N$-acetylglucosaminidase; NAG) [53], IVA ( $N$-acetylgalactosamine6-sulfatase; GALNS) [54], and VI (Arylsulfatase B; ARSB) [55]. Leukocyte isolation from 2-3 mL EDTA blood and protein determination are required prior to performing the enzyme assay. Proteins are determined using Coomassie Plus protein assay reagent (Pierce). The assay for individual enzyme activity is carried out using 4-methylumbelliferyl substrate. The enzyme activity is proportional to the amount of liberated fluorescence detected (excitation, $365 \mathrm{~nm}$; emission, $450 \mathrm{~nm}$ ) with a Victor $\mathrm{Nivo}^{\mathrm{TM}}$ Multimode plate reader (Perkin Elmer). The enzyme activity is expressed as $\mu$ mol enzyme activity/g protein/hour. An individual enzyme's activity which is $5 \%$ lower than that of the normal population is defined as being a marked reduction in terms of the activity of that enzyme.

All urine samples were stored at $-20{ }^{\circ} \mathrm{C}$ prior to analysis $[12,17,18]$. The subjects with elevated urinary GAG levels by the DMB spectrophotometry method and abnormal GAG-derived disaccharide 
patterns by 2-D EP, and elevated urinary DS, HS, or KS levels by the LC-MS/MS method, were recalled for specific enzymatic activity assays in leukocytes by fluorometry for a confirmative diagnosis. Elevated levels of DS and HS indicated MPS I (alpha-iduronidase) and MPS II (iduronate-2-sulfatase), an elevated level of HS indicated MPS III (heparan $N$-sulfatase in type A, alpha- $N$-acetylglucosaminidase in type B, acetyl $\mathrm{CoA}$-alpha-glucosaminide acetyltransferase in type $\mathrm{C}$, and $\mathrm{N}$-acetylglucosamine 6-sulfatase in type D), elevated levels of KS and CS indicated MPS IVA (galactose-6-sulfate sulfatase), an elevated level of KS only indicated MPS IVB (beta-galactosidase), an elevated level of DS indicated MPS VI (arylsulfatase B), and elevated levels of DS, HS, and CS indicated MPS VII (beta-glucuronidase). The patients with an enzyme activity $<5 \%$ of the mean of normal population underwent genetic testing and counseling. The study protocol was approved by the Ethics Committee of MacKay Memorial Hospital, and written informed consent was provided by a parent of the children and from the patients themselves if they were over 18 years of age.

Table 1. Signs and symptoms of mucopolysaccharidoses in different organs and systems.

\begin{tabular}{|c|c|}
\hline Organs and Systems & Signs and Symptoms \\
\hline Musculoskeletal system & $\begin{array}{l}\text { Skeletal malformations, joint stiffness or hypermobility, } \\
\text { short stature, kyphoscoliosis, carpal tunnel syndrome }\end{array}$ \\
\hline Neurological system & Psychomotor delay, cognitive delay, behavioral disorders \\
\hline Face & Coarse facial features \\
\hline Connective tissue & Hernias \\
\hline Heart & Valvulopathy, myocardiopathy \\
\hline Visceromegaly & Hepatomegaly, splenomegaly \\
\hline Respiratory system & Recurrent respiratory infection, noisy breath sounds \\
\hline Otorhinolaryngological system & $\begin{array}{l}\text { Recurrent otitis media, hearing impairment, recurrent } \\
\text { sinusitis, obstructive sleep apnea syndrome }\end{array}$ \\
\hline Ophthalmological system & Cornea clouding, retinopathy \\
\hline
\end{tabular}

\subsection{Normal Reference Values of Urinary GAGs}

In our previous study, the normal reference values of the three urinary GAGs (DS, HS, and KS) using the LC-MS/MS method, and the non-specific total level of urinary GAGs (DMB/creatinine ratio) using the dye-based method, were determined from 221 urine samples of healthy controls. The reference values were divided into five age groups as follows: 0-1 years, 1-3 years, 4-9 years, 10-17 years, and $>18$ years of age. The normal reference ranges of DS, HS, and KS were consistent among the five age groups; however, the normal reference ranges of the DMB ratio decreased as the age of the normal controls increased [56].

\subsection{Clinical Characteristics of Patients with a Confirmative Diagnosis of MPS}

For patients with a confirmative diagnosis of MPS, we recorded the clinical characteristics including the MPS type, gender, urinary DS, HS, KS and DMB ratio for which a medical specialist referred the patient for testing, and the existence of clinical manifestations at the time of diagnosis including the involvement of the musculoskeletal system, ophthalmological system, respiratory system, otorhinolaryngological system and neurological system, and cardiac disease, hernia, hepatosplenomegaly, coarse face, hearing impairment, family history of MPS, and whether they had received surgery before the diagnosis.

\subsection{Statistical Analysis}

All results were analyzed using descriptive statistics, including numbers and percentages for categorical variables, and mean, median, and range (minimum and maximum values) for continuous variables. The results were presented as mean \pm standard deviation unless otherwise indicated. False negatives were defined as MPS patients with normal results of urinary DMB ratio or urinary DS, HS and KS levels. 


\section{Results}

Figure 1 shows the age distribution of the 153 subjects who were enrolled in this study. One hundred and thirteen subjects (74\%) were between 0-6 years of age. Forty urine samples sent to our laboratory for at-risk screening for MPS were delivered by pediatric endocrinologists $(26 \%)$, followed by pediatric neurologists $(25 \%)$ and general pediatricians $(22 \%)$ (Table 2$)$. The major signs and symptoms according to the involved system recorded by health care professionals at the time of the decision to test were the musculoskeletal system (55\%), followed by the neurological system $(45 \%)$ and coarse facial features (39\%) (Table 3). Twenty-two subjects had elevated urinary GAG levels and abnormal GAG disaccharide pattern by 2-D EP, and elevated urinary DS, HS, or KS levels, and they were recalled for specific enzyme activity assays in leukocytes for a confirmative diagnosis. The patients with an enzyme activity level $<5 \%$ of the mean of normal population underwent genetic testing. Among them, 13 patients had a confirmative diagnosis of MPS (nine males and four females; age range, 0.6 to 10.9 years; median age, 2.9 years; mean age, $3.4 \pm 2.9$ years; three with MPS I, four with MPS II, five with MPS IIIB, and one with MPS IVA). Three patients (23\%) were identified before 1 year of age, and seven patients $(54 \%)$ were diagnosed before 3 years of age. The false negative rate of the urinary $\mathrm{DMB} /$ creatinine ratio for these 13 patients was $31 \%$, including one MPS I, two MPS IIIB, and one MPS IVA. However, there were no false negative results observed from urinary DS, HS and KS quantifications (Table 4). All 13 patients with MPS had musculoskeletal system involvement, followed by $85 \%$ with coarse facial features, $54 \%$ with otorhinolaryngological system involvement, $38 \%$ with visceromegaly, $38 \%$ with hernia, and $38 \%$ with neurological system involvement. Two patients diagnosed with MPS II and IVA, respectively, did not have coarse facial features. All five patients with MPS IIIB had speech delay and/or attention deficit. Seven patients (54\%) had received surgical procedures before the diagnosis of MPS, including five hernia repairs and three ventilation tube insertions. Six MPS patients were suspected and referred by pediatric neurologists ( $46 \%$ ), followed by three patients referred by pediatric orthopedists $(23 \%)$, and one patient was referred by a pediatric cardiologist, neonatologist, geneticist, and general pediatrician, respectively (Table 5). Intravenous ERT was started in eight patients (Nos. 1-7 and No. 13) following the diagnosis. Patient No. 1 also received HSCT at 1.6 years of age. Patient No. 8 was enrolled in a phase I/II trial of intracerebroventricular enzymatic therapy for MPS IIIB.

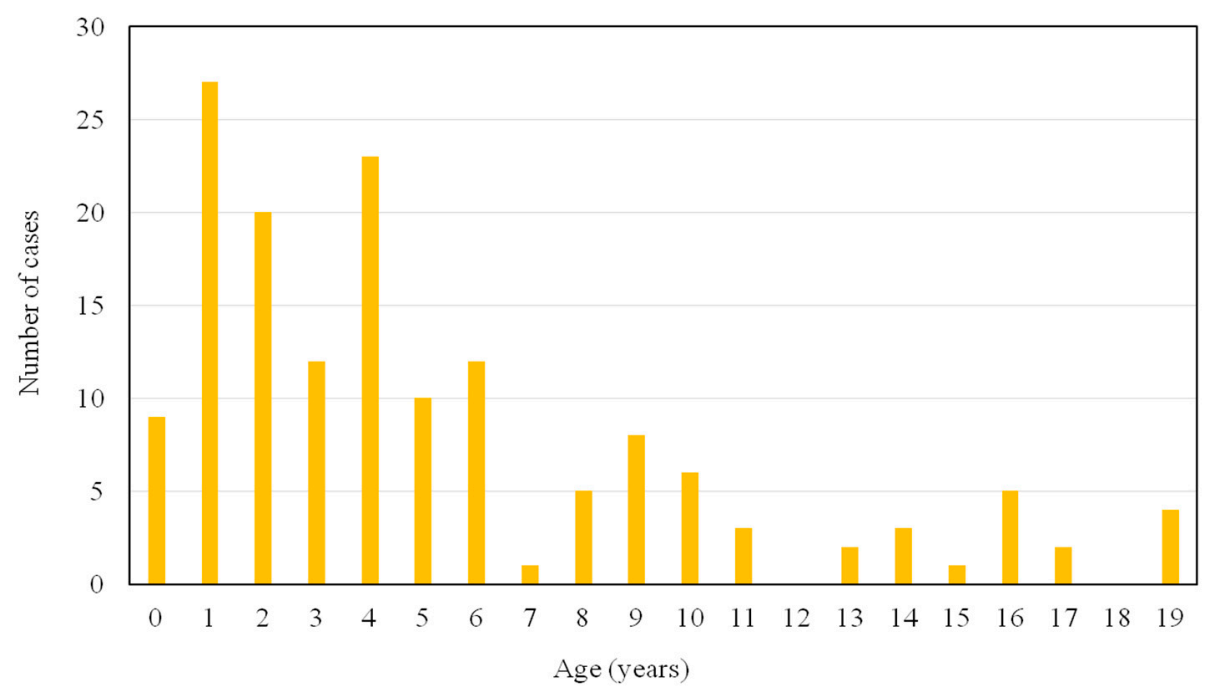

Figure 1. The age distribution of the 153 urine samples collected in this study. 
Table 2. Number and percentage of different specialists who sent the urine sample to our laboratory for at-risk population screening for mucopolysaccharidoses.

\begin{tabular}{ccc}
\hline Specialist & Number & Percentage \\
\hline Pediatric endocrinologist & 40 & $26 \%$ \\
Pediatric neurologist & 39 & $25 \%$ \\
General pediatrician & 34 & $22 \%$ \\
Geneticist & 17 & $11 \%$ \\
Pediatric rheumatologist & 6 & $4 \%$ \\
Neonatologist & 6 & $4 \%$ \\
Pediatric orthopedist & 5 & $3 \%$ \\
Pediatric cardiologist & 5 & $3 \%$ \\
Pediatric surgeon & 1 & $1 \%$ \\
Total & 153 & $100 \%$ \\
\hline
\end{tabular}

Table 3. Signs and symptoms by different systems recorded by health care professionals at the time of the decision to test the 153 subjects suspected of having mucopolysaccharidosis (MPS).

\begin{tabular}{ccc}
\hline Signs and Symptoms by Different Systems & Number & Percentage \\
\hline Musculoskeletal system & 84 & $55 \%$ \\
Neurological system & 69 & $45 \%$ \\
Face & 59 & $39 \%$ \\
Hernias & 13 & $8 \%$ \\
Heart & 10 & $7 \%$ \\
Visceromegalies & 9 & $6 \%$ \\
Respiratory system & 7 & $5 \%$ \\
Hearing system & 5 & $3 \%$ \\
Ophthalmological system & 4 & $3 \%$ \\
Otorhinolaryngological system & 4 & $3 \%$ \\
Family history of MPS & 3 & $2 \%$ \\
Total & 267 & \\
\hline
\end{tabular}


Table 4. Demographic data, urine glycosaminoglycans (GAG) levels, enzymatic activity, and genotype of the 13 MPS patients at the time of a confirmative diagnosis.

\begin{tabular}{|c|c|c|c|c|c|c|c|c|c|c|c|c|}
\hline No. & $\begin{array}{l}\text { MPS } \\
\text { type }\end{array}$ & Gender & $\begin{array}{c}\text { Age at } \\
\text { Diagnosis } \\
\text { (years) }\end{array}$ & $\begin{array}{c}\mathrm{DS} \\
(\mu \mathrm{g} / \mathrm{mL})\end{array}$ & $\begin{array}{c}\mathrm{HS} \\
(\mu \mathrm{g} / \mathrm{mL})\end{array}$ & $\underset{(\mu \mathrm{g} / \mathrm{mL})}{\mathrm{KS}}$ & $\begin{array}{l}\text { DMB Ratio } \\
\text { (mg/mmol } \\
\text { creatinine) }\end{array}$ & $\begin{array}{c}{ }^{*} \text { DMB } \\
\text { Reference Range } \\
\text { (mg/mmol creatinine) }\end{array}$ & Enzyme & $\begin{array}{l}\text { Enzymatic } \\
\text { Activity }\end{array}$ & Gene & Genotype \\
\hline 1 & I & $\mathrm{F}$ & 0.6 & 322.1 & 5.0 & 3 & 113.62 & $<69.15$ & Alpha-iduronidase & $\begin{array}{l}0.3 \mathrm{nmol} / \mathrm{mg} \\
\text { protein } / \mathrm{h}\end{array}$ & IDUA & c.590-7G > A/c.1861C > T \\
\hline 2 & I & $\mathrm{F}$ & 0.7 & 174 & 3.9 & 2.79 & 159.51 & $<69.15$ & Alpha-iduronidase & $\begin{array}{l}0.39 \mathrm{nmol} / \mathrm{mg} \\
\text { protein } / \mathrm{h}\end{array}$ & IDUA & $\begin{array}{c}\text { c.1192_1194delGAG/c.1634delA, } \\
\text { c.1634_1635insGGG }\end{array}$ \\
\hline 3 & I & $\mathrm{F}$ & 2.9 & 147.66 & 21.71 & 0.7 & 49.78 & $<58.82$ & Alpha-iduronidase & $\begin{array}{l}0.87 \mathrm{nmol} / \mathrm{mg} \\
\text { protein/h }\end{array}$ & IDUA & c. $95 \mathrm{~T}>\mathrm{G}$ \\
\hline 4 & II & M & 0.9 & 78.69 & 176.3 & 0 & 185.43 & $<69.15$ & Iduronate-2-sulfatase & $\begin{array}{l}0.1 \mathrm{nmol} / \mathrm{mg} \\
\text { protein/ } 4 \mathrm{~h}\end{array}$ & IDS & c.137A > C (hemizygous) \\
\hline 5 & II & M & 3.8 & 127.69 & 109.75 & 6.31 & 61.29 & $<58.82$ & Iduronate-2-sulfatase & $\begin{array}{l}0.4 \mathrm{nmol} / \mathrm{mg} \\
\text { protein } / 4 \mathrm{~h}\end{array}$ & IDS & c.1122C > T (hemizygous) \\
\hline 6 & II & M & 6.3 & 51.8 & 0 & 1.51 & 37.60 & $<18.20$ & Iduronate-2-sulfatase & $\begin{array}{l}0.2 \mathrm{nmol} / \mathrm{mg} \\
\text { protein } / 4 \mathrm{~h}\end{array}$ & IDS & c.1600A > C (hemizygous) \\
\hline 7 & II & M & 10.9 & 91.93 & 384.03 & 0.22 & 27.03 & $<16.81$ & Iduronate-2-sulfatase & $\begin{array}{l}0.86 \mathrm{nmol} / \mathrm{mg} \\
\text { protein/ } 4 \mathrm{~h}\end{array}$ & IDS & c. $1006+5 G$ > C (hemizygous) \\
\hline 8 & IIIB & M & 1.3 & 0 & 92.43 & 3.59 & 55.35 & $<58.82$ & $\mathrm{~N}$-acetyl-glucosaminidase & $\begin{array}{l}0.05 \mathrm{nmol} / \mathrm{mg} \\
\text { protein/h }\end{array}$ & NAGLU & c. $383+1 \mathrm{G}>\mathrm{T} / \mathrm{c} .1693 \mathrm{C}>\mathrm{T}$ \\
\hline 9 & IIIB & M & 1.8 & 0.3 & 179.2 & 0.36 & 65.23 & $<58.82$ & $\mathrm{~N}$-acetyl-glucosaminidase & $\begin{array}{l}0.06 \mathrm{nmol} / \mathrm{mg} \\
\text { protein/h }\end{array}$ & NAGLU & c.252_253ins19/c.1493T > C \\
\hline 10 & IIIB & M & 3.4 & 0 & 48.59 & 2.68 & 47.20 & $<58.82$ & $\mathrm{~N}$-acetyl-glucosaminidase & $\begin{array}{l}0.07 \mathrm{nmol} / \mathrm{mg} \\
\text { protein/h }\end{array}$ & NAGLU & c. $383+1 \mathrm{G}>\mathrm{T} / \mathrm{c} .1693 \mathrm{C}>\mathrm{T}$ \\
\hline 11 & IIIB & M & 4.7 & 0.9 & 58.1 & 0.06 & 22.52 & $<18.20$ & $\mathrm{~N}$-acetyl-glucosaminidase & $\begin{array}{l}0.04 \mathrm{nmol} / \mathrm{mg} \\
\text { protein/h }\end{array}$ & NAGLU & c. $.926 \mathrm{~A}>\mathrm{G} / \mathrm{c} .1241 \mathrm{~A}>\mathrm{G}$ \\
\hline 12 & IIIB & $\mathrm{F}$ & 5.0 & 0.14 & 11.54 & 0.01 & 55.85 & $<18.20$ & $\mathrm{~N}$-acetyl-glucosaminidase & $\begin{array}{l}0.2 \mathrm{nmol} / \mathrm{mg} \\
\text { protein/h }\end{array}$ & NAGLU & $\begin{array}{c}\text { c. } 1693 \mathrm{C}>\mathrm{A} / \mathrm{c} .1693 \mathrm{C}>\mathrm{A} \\
\text { (homozygous) }\end{array}$ \\
\hline 13 & IVA & M & 1.5 & 0.04 & 0.01 & 90.28 & 45.27 & $<58.82$ & $\begin{array}{l}\text { Galactose-6-sulfate } \\
\text { sulfatase }\end{array}$ & $\begin{array}{l}0.3 \mathrm{nmol} / \mathrm{mg} \\
\text { protein/h }\end{array}$ & GALNS & c. $953 \mathrm{~T}>\mathrm{G} / \mathrm{c} .1567 \mathrm{~T}>\mathrm{G}$ \\
\hline
\end{tabular}

GAG, glycosaminoglycans; MPS, mucopolysaccharidosis; DS, dermatan sulfate; HS, heparan sulfate; KS, keratan sulfate; DMB, dimethylmethylene blue. Reference range: DS $<0.43 \mu \mathrm{g} / \mathrm{mL}$, $\mathrm{HS}<0.46 \mu \mathrm{g} / \mathrm{mL}, \mathrm{KS}<7.90 \mu \mathrm{g} / \mathrm{mL}$. *Reference ranges of DMB are age dependent: $0-1$ year, $<69.15 ; 1-3$ years, $<58.82 ; 4-9$ years, $<18.20 ; 10-17$ years, $<16.81 ;>18$ years, $<12.75 \mathrm{mg} / \mathrm{mmol}$ creatinine [42]. 
Table 5. Clinical characteristics of the 13 MPS patients at the time of a confirmative diagnosis.

\begin{tabular}{|c|c|c|c|c|c|c|c|c|c|c|c|c|c|c|c|c|}
\hline No. & $\begin{array}{l}\text { MPS } \\
\text { type }\end{array}$ & Gender & $\begin{array}{c}\text { Age at } \\
\text { Diagnosis } \\
\text { (years) }\end{array}$ & $\begin{array}{l}\text { Referring } \\
\text { Specialist }\end{array}$ & $\begin{array}{l}\text { Musculoskeletal } \\
\text { System }\end{array}$ & $\begin{array}{l}\text { Ophthalmological } \\
\text { System }\end{array}$ & Heart & $\begin{array}{l}\text { Neurological } \\
\text { System }\end{array}$ & Hernias & Visceromegaly & Face & $\begin{array}{l}\text { Respiratory } \\
\text { System }\end{array}$ & $\begin{array}{l}\text { Otorhinolaryngological } \\
\text { System }\end{array}$ & $\begin{array}{l}\text { Hearing } \\
\text { System }\end{array}$ & $\begin{array}{l}\text { Family } \\
\text { History } \\
\text { of MPS }\end{array}$ & $\begin{array}{c}\text { Surgeries } \\
\text { before a } \\
\text { Confirmative } \\
\text { Diagnosis }\end{array}$ \\
\hline 1 & I & F & 0.6 & Neonatologist & Y & $\mathrm{N}$ & $\mathrm{N}$ & $\mathrm{N}$ & Y & $\mathrm{N}$ & Y & Y & Y & $\mathrm{N}$ & M & $\begin{array}{l}\text { Herniorrhaphy, } \\
\text { supraglottoplasty } \\
\text { for } \\
\text { laryngomalacia, } \\
\text { tracheostomy }\end{array}$ \\
\hline 2 & I & F & 0.7 & $\begin{array}{c}\text { Pediatric } \\
\text { orthopedist }\end{array}$ & Y & $\mathrm{N}$ & $\mathrm{N}$ & $\mathrm{N}$ & $\mathrm{N}$ & $\mathrm{N}$ & Y & $\mathrm{N}$ & N & N & $\mathrm{N}$ & None \\
\hline 3 & I & F & 2.9 & $\begin{array}{c}\text { Pediatric } \\
\text { cardiologist }\end{array}$ & Y & $\mathrm{N}$ & Y & $\mathrm{N}$ & $\mathrm{N}$ & Y & Y & Y & $\mathrm{N}$ & $\mathrm{N}$ & $\mathrm{N}$ & None \\
\hline 4 & II & M & 0.9 & Geneticist & Y & $\mathrm{N}$ & N & $\mathrm{N}$ & Y & Y & Y & $\mathrm{N}$ & $\mathrm{N}$ & N & $\mathrm{N}$ & $\begin{array}{c}\text { Surgery for } \\
\text { spina bifida, } \\
\text { herinorrhaphy }\end{array}$ \\
\hline 5 & II & M & 3.8 & $\begin{array}{c}\text { Pediatric } \\
\text { orthopedist }\end{array}$ & Y & $\mathrm{N}$ & $\mathrm{N}$ & $\mathrm{N}$ & $\mathrm{Y}$ & $\mathrm{N}$ & $\mathrm{Y}$ & $\mathrm{N}$ & $\mathrm{N}$ & N & $\mathrm{N}$ & Herinorrhaphy \\
\hline 6 & II & M & 6.3 & $\begin{array}{c}\text { Pediatric } \\
\text { neurologist }\end{array}$ & Y & $\mathrm{N}$ & $\mathrm{N}$ & $\mathrm{N}$ & Y & $\mathrm{N}$ & $\mathrm{N}$ & Y & Y & Y & $\mathrm{N}$ & $\begin{array}{l}\text { Ventilation tube } \\
\text { insertion, } \\
\text { tonsillectomy, } \\
\text { adenoidectomy, } \\
\text { herniorrhaphy }\end{array}$ \\
\hline 7 & II & M & 10.9 & $\begin{array}{c}\text { Pediatric } \\
\text { neurologist }\end{array}$ & Y & $\mathrm{N}$ & Y & $\mathrm{N}$ & Y & Y & Y & $\mathrm{N}$ & Y & $\mathrm{N}$ & $\mathrm{N}$ & Herinorrhaphy \\
\hline 8 & IIIB & M & 1.3 & $\begin{array}{c}\text { Pediatric } \\
\text { neurologist }\end{array}$ & Y & $\mathrm{N}$ & $\mathrm{N}$ & Y & $\mathrm{N}$ & Y & Y & $\mathrm{N}$ & Y & Y & Y & None \\
\hline 9 & IIIB & M & 1.8 & $\begin{array}{c}\text { General } \\
\text { pediatrician }\end{array}$ & Y & $\mathrm{N}$ & $\mathrm{N}$ & Y & $\mathrm{N}$ & $\mathrm{N}$ & Y & $\mathrm{N}$ & $\mathrm{N}$ & $\mathrm{N}$ & $\mathrm{N}$ & None \\
\hline 10 & IIIB & M & 3.4 & $\begin{array}{c}\text { Pediatric } \\
\text { neurologist }\end{array}$ & Y & $\mathrm{N}$ & $\mathrm{N}$ & Y & $\mathrm{N}$ & Y & Y & $\mathrm{N}$ & Y & $\mathrm{N}$ & Y & None \\
\hline 11 & IIIB & M & 4.7 & $\begin{array}{c}\text { Pediatric } \\
\text { neurologist }\end{array}$ & Y & $\mathrm{N}$ & Y & Y & $\mathrm{N}$ & N & Y & Y & Y & $\mathrm{N}$ & $\mathrm{N}$ & $\begin{array}{l}\text { Ventilation tube } \\
\text { insertion }\end{array}$ \\
\hline 12 & IIIB & $\mathrm{F}$ & 5.0 & $\begin{array}{c}\text { Pediatric } \\
\text { neurologist }\end{array}$ & Y & $\mathrm{N}$ & N & Y & $\mathrm{N}$ & $\mathrm{N}$ & Y & $\mathrm{N}$ & Y & Y & $\mathrm{N}$ & $\begin{array}{l}\text { Ventilation tube } \\
\text { insertion }\end{array}$ \\
\hline 13 & IVA & M & 1.5 & $\begin{array}{c}\text { Pediatric } \\
\text { orthopedist }\end{array}$ & Y & $\mathrm{N}$ & $\mathrm{N}$ & $\mathrm{N}$ & $\mathrm{N}$ & $\mathrm{N}$ & $\mathrm{N}$ & $\mathrm{N}$ & N & N & $\mathrm{N}$ & None \\
\hline
\end{tabular}

MPS, mucopolysaccharidosis; $\mathrm{M}$, male; F, female; $\mathrm{Y}$, yes; $\mathrm{N}$, no. 


\section{Discussion}

To the best of our knowledge, this is the first study to report screening for MPS in an at-risk population in Taiwan by measuring urinary GAG fractionation biomarkers using the LC-MS/MS method, which has been shown to be a powerful and reliable tool for MPS high-risk screening and diagnostic purposes. We established this screening platform with the participation of medical geneticists and other medical specialists to increase awareness and enable an early diagnosis by detecting MPS at the initial onset of clinical symptoms. In this study, three patients $(23 \%)$ were identified before 1 year of age, and seven patients (54\%) were diagnosed before 3 years of age, emphasizing the value of this sign and symptom-based screening program in making an early diagnosis of MPS by raising clinical awareness and educating health care professionals. Colón et al. [57] reported that they diagnosed eight patients with different types of MPS (one with MPS I, one with MPS II, two with MPS IIIA, one with MPS IIIB, two with MPS IVA, and one with MPS VI) by performing a selective screening program for the early detection of MPS from 2014 to 2016. In their cohort, two cases were identified before 1 year of age, and six cases were detected before 3 years of age, which corresponds well with our results. However, compared to their measurement of urinary GAG levels using only the DMB spectrophotometry method and abnormal GAG disaccharide pattern by 2-D EP, we also measured urinary DS, HS, and KS levels using the LC-MS/MS method at the same time. If any of the data were abnormally elevated, the subjects were recalled for specific enzymatic activity assays in leukocytes by fluorometry for a confirmative diagnosis. In this study, the false negative rate of the urinary DMB ratio using the spectrophotometric method for the 13 MPS patients was 31\%, including one MPS I, two MPS IIIB, and one MPS IVA. Nevertheless, there were no false negative results of urinary DS, HS and KS using the LC-MS/MS method. Auray-Blais et al. [15] reported that the DMB spectrophotometric method can lead to false negative results because of aggregated formation through electrostatic interactions with albumin, glycoproteins, collagen, and other serum proteins which may modify the physicochemical properties of GAGs, especially in MPS III and IV [14]. In their study, the DMB spectrophotometric method missed the identification of MPS in 30\% of their patients (7/23) (one with MPS II, one with MPS III, four with MPS IVA, and one with MPS VI), revealing that this method is relatively unreliable for screening MPS patients, which also corresponds well with our results. Therefore, we recommend that measuring GAG fractionation biomarkers with the LC-MS/MS method is an accurate and reliable method to concurrently quantify urinary levels of DS, HS and KS, and that these biomarkers are more sensitive compared to the traditional DMB ratio using the spectrophotometric method to diagnose MPS, identify subgroups, and screen high-risk populations.

It is well-known that urine GAG is different from blood GAG. The limitation of $\mathrm{uKS}$ in its use as a biomarker to prove therapeutic efficacy is distinct. A large amount of literature has revealed that uGAG is not an appropriate biomarker for monitoring therapeutic effects [58]. According to the experimental findings reported by Saville J.T. et al., the concentration of oligosaccharides and the ratio of HS:DS in urine were similar to those observed in the kidney, suggesting that the oligosaccharide storage pattern in urine is a reflection of that in the kidney. Although serum, liver and brain had a similar ratio of HS:DS, which was lower than that seen in the urine and kidney, a distribution of oligosaccharides which ranked from most to least abundant between serum, liver and brain was observed, suggesting that serum more closely reflects the oligosaccharides of the brain and liver and may therefore be a more informative measurement of disease burden than urine [59]. In addition, Kahn et al. [47] and Fujitsuka et al. [60] also stated that blood KS remained high while uKS was reduced during ERT. The fact of the lack of a reduction of blood KS should be notable because this is critical evidence that uKS is ineffective as a biomarker to prove therapeutic efficacy.

Different types of MPS have many similar clinical features and some type-specific manifestations. The severe forms of MPS I and II present with both somatic and cognitive involvement and are characterized by coarse facial features, vision and hearing impairment, recurrent respiratory infections, decreased pulmonary function, obstructive sleep apnea, cardiac disease, inguinal and umbilical hernias, hepatosplenomegaly, spinal cord compression, communicating hydrocephalus, and dysostosis 
multiplex [56,61]. MPS III manifests as neurological and cognitive impairment and mild somatic involvement [62]. MPS IV presents as short stature, odontoid hypoplasia, ligamentous laxity, joint hypermobility, and skeletal dysplasia [63]. MPS VI is characterized by a purely somatic manifestation similar to MPS I and II without cognitive involvement [1-3]. In our study, at the time of diagnosis, all 13 MPS patients had musculoskeletal system involvement, followed by $85 \%$ with coarse facial features, $54 \%$ with otorhinolaryngological system involvement, $38 \%$ with visceromegaly, $38 \%$ with hernia, and $38 \%$ with neurological system involvement. All five MPS IIIB patients had a speech delay and/or attention deficit. None of the patients had cornea clouding, and one MPS II patient and one MPS IVA patient did not have coarse facial features when they were diagnosed.

Using data from an MPS I registry $(n=544)$, Arn et al. [64] reported that at least one surgery preceded the diagnosis in $36 \%, 46 \%$, and $63 \%$ of the patients with Hurler, Hurler-Scheie, and Scheie syndromes, respectively. In addition, more than one-third (39\%) of all patients had hernia repair surgery before they were diagnosed with MPS I. Using data from the Hunter Outcome Survey $(n=389)$, Mendelsohn et al. [65] reported that the majority of patients (57\%) underwent at least one surgical intervention before the diagnosis of MPS II, and that $55 \%$ and $45 \%$ of the patients underwent hernia repair and tympanostomy, respectively, before MPS II was diagnosed. In our cohort, seven patients $(54 \%)$ received surgical procedures before the diagnosis of MPS, including five with hernia repair and three with ventilation tube insertion, which is consistent with Mendelsohn et al.'s study. These findings indicate that health care professionals need to be aware of the surgical burden of MPS as well as its presenting signs and symptoms and the importance of timely referral for MPS diagnostic testing.

A delayed diagnosis of MPS is often due to referrals from one physician to another. This is mainly because of the rare nature of the disorder, phenotypic heterogeneity, and the broad range of nonspecific early signs and symptoms [35]. As a consequence, in addition to medical geneticists, it is important that general health care professionals are aware of the early signs and symptoms of MPS. In this prospective study, we established an at-risk population screening program for MPS that involved the participation of medical geneticists and other medical specialists, including pediatric endocrinologists, pediatric neurologists, general pediatricians, pediatric rheumatologists, neonatologists, pediatric orthopedists, pediatric cardiologists, and pediatric surgeons. Among the 13 patients diagnosed with MPS, 46\% were referred by pediatric neurologists, followed by pediatric orthopedists $(23 \%)$. Other patients were referred by pediatric cardiologists, neonatologists, geneticists, and a general pediatrician.

Although ERT and HSCT cannot cure MPS disorders, they can improve or lessen the natural progression, and better outcomes may be related to commencing these treatments at a younger age [32-34]. The increasing clinical awareness of MPS disease and increased ability to make a confirmative diagnosis has made an earlier diagnosis possible. In this study, eight of the 13 patients diagnosed with MPS started to receive ERT, for which the payments were reimbursed by the Taiwanese National Health Insurance program following international standards. In addition, one MPS I patient also received HSCT, and one MPS IIIB patient enrolled in a phase I/II clinical trial.

\section{Limitations}

Previous studies have reported that elevated GAG levels may be due to conditions unrelated to MPS, including arthritis, diabetes, and mucolipidosis [66,67]. In addition, the small sample size with each type of MPS with a confirmative diagnosis is also a limitation to this study. However, this reflects the rare nature of this genetic disorder. Meanwhile, the degree of disease severity was quite wide, as was the range of age at diagnosis. Thus, further studies with a longer follow-up period and larger cohorts are warranted.

\section{Conclusions}

We established an at-risk population screening program for MPS by measuring urinary GAG fractionation biomarkers using the LC-MS/MS method and included medical geneticists and other medical specialists to increase awareness and enable an early diagnosis by detecting MPS at the initial 
onset of clinical symptoms. This method appears to be accurate and reliable to simultaneously quantify urinary levels of DS, HS and KS, which have been shown to be more sensitive than the traditional DMB ratio using the spectrophotometric method to diagnose MPS, identify subgroups, and screen high-risk populations. Due to the progressive nature of MPS, initiating ERT or HSCT before the occurrence of irreversible organ damage may contribute to a better clinical outcome. Thus, making an early diagnosis through screening programs for high-risk populations or newborns is very important $[57,68,69]$.

Author Contributions: H.-Y.L. performed the acquisition, statistical analysis and interpretation of data, and drafting of the manuscript. S.-P.L. and C.-K.C. participated in the design of the study and interpretation of the data and helped to draft the manuscript. Y.-T.L. and R.-Y.T. performed biochemical analyses and revised the manuscript. C.-L.L., Y.-H.C., C.-Y.C., P.C.C., T.-M.C., W.-H.T. and D.-M.N. were responsible for patient screening and revised the manuscript. All authors read and accepted the manuscript.

Funding: This study was supported by research grants from the Ministry of Science and Technology, Executive Yuan, Taiwan (MOST-108-2314-B-195-012, MOST-108-2314-B-195-014, MOST-106-2314-B-195-015-MY2, and MOST-105-2628-B-195-001-MY3) and MacKay Memorial Hospital (MMH-E-108-16 and MMH-107-82). The authors confirm independence from the sponsors. The contents of the article, including the design of the study and collection, analysis, and interpretation of data and in writing the manuscript, have not been influenced by the sponsors.

Acknowledgments: We acknowledge the participation of study patients and their families. This study was supported by research grants from the Ministry of Science and Technology, Executive Yuan, Taiwan (MOST-108-2314B-195-012, MOST-108-2314-B-195-014, MOST-106-2314-B-195-015-MY2, and MOST-105-2628-B-195-001-MY3) and MacKay Memorial Hospital (MMH-E-108-16 and MMH-107-82). The authors thank Tsai-Feng Ho for her professional assistance in biostatistics.

Conflicts of Interest: The authors declare no conflict of interest.

\section{Abbreviations}

$\begin{array}{ll}\text { MPS } & \text { Mucopolysaccharidosis } \\ \text { GAGs } & \text { Glycosaminoglycans } \\ \text { DS } & \text { Dermatan sulfate } \\ \text { HS } & \text { Heparan sulfate } \\ \text { KS } & \text { Keratan sulfate } \\ \text { CS } & \text { Chondroitin sulfate } \\ \text { 2-D EP } & \text { Two-dimensional electrophoresis } \\ \text { DMB } & \text { Dimethylmethylene blue } \\ \text { LC-MS/MS } & \text { Liquid chromatography/tandem mass spectrometry } \\ \text { ERT } & \text { Enzyme replacement therapy } \\ \text { HSCT } & \text { Hematopoietic stem cell transplantation }\end{array}$

\section{References}

1. Neufield, E.F.; Muenzer, J. The mucopolysaccharidoses. In The Metabolic and Molecular Bases of Inherited Disease, 8th ed.; McGraw-Hill: New York, NY, USA, 2001; Volume 136, pp. 3421-3452.

2. Muenzer, J. The Mucopolysaccharidoses: A heterogeneous group of disorders with variable pediatric presentations. J. Pediatr. 2004, 144, S27-S34. [CrossRef]

3. Muenzer, J. Overview of the Mucopolysaccharidoses. Rheumatology (Oxford) 2011, 50 (Suppl. 5), v4-v12. [CrossRef]

4. Lee, C.L.; Lin, H.Y.; Chuang, C.K.; Chiu, H.C.; Tu, R.Y.; Huang, Y.H.; Hwu, W.L.; Tsai, F.J.; Chiu, P.C.; Niu, D.M.; et al. Functional independence of Taiwanese patients with Mucopolysaccharidoses. Mol. Genet. Genomic. Med. 2019, 7, e790. [CrossRef]

5. Lin, H.Y.; Chan, W.C.; Chen, L.J.; Lee, Y.C.; Yeh, S.I.; Niu, D.M.; Chiu, P.C.; Tsai, W.H.; Hwu, W.L.; Chuang, C.K.; et al. Ophthalmologic Manifestations in Taiwanese Patients with Mucopolysaccharidoses. Mol. Genet. Genomic. Med. 2019, 7, e00617. [CrossRef]

6. $\quad$ Lin, H.Y.; Shih, S.C.; Chuang, C.K.; Lee, K.S.; Chen, M.R.; Lin, H.C.; Chiu, P.C.; Niu, D.M.; Lin, S.P. Assessment of hearing loss by pure-tone audiometry in patients with Mucopolysaccharidoses. Mol. Genet. Metab. 2014, 111, 533-538. [CrossRef] 
7. Lin, S.P.; Shih, S.C.; Chuang, C.K.; Lee, K.S.; Chen, M.R.; Niu, D.M.; Chiu, P.C.; Lin, S.J.; Lin, H.Y. Characterization of Pulmonary Function Impairments in Patients with Mucopolysaccharidoses-Changes with Age and Treatment. Pediatr. Pulmonol. 2014, 49, 277-284. [CrossRef]

8. Lin, H.Y.; Chen, M.R.; Lin, C.C.; Chen, C.P.; Lin, D.S.; Chuang, C.K.; Niu, D.M.; Chang, J.H.; Lee, H.C.; Lin, S.P. Polysomnographic characteristics in patients with Mucopolysaccharidoses. Pediatr. Pulmonol. 2010, 45, 1205-1212. [CrossRef]

9. Lin, S.M.; Lin, H.Y.; Chuang, C.K.; Lin, S.P.; Chen, M.R. Cardiovascular abnormalities in Taiwanese patients with Mucopolysaccharidosis. Mol. Genet. Metab. 2014, 111, 493-498. [CrossRef] [PubMed]

10. Lin, H.Y.; Shih, S.C.; Chuang, C.K.; Chen, M.R.; Niu, D.M.; Lin, S.P. Assessment of Bone Mineral Density by Dual Energy X-ray Absorptiometry in Patients with Mucopolysaccharidoses. Orphanet. J. Rare Dis. 2013, 8, 71. [CrossRef] [PubMed]

11. Lin, H.Y.; Lin, S.P.; Chuang, C.K.; Niu, D.M.; Chen, M.R.; Tsai, F.J.; Chao, M.C.; Chiu, P.C.; Lin, S.J.; Tsai, L.P.; et al. Incidence of the Mucopolysaccharidoses in Taiwan, 1984-2004. Am. J. Med. Genet. A 2009, 149A, 960-964. [CrossRef] [PubMed]

12. Chuang, C.K.; Lin, S.P.; Chung, S.F. Diagnostic screening for Mucopolysaccharidoses by the dimethylmethylene blue method and two dimensional electrophoresis. Zhonghua Yi Xue Za Zhi (Taipei) 2001, 64, 15-22. [PubMed]

13. Chuang, C.K.; Lin, S.P.; Lee, S.J.; Wang, T.J. MPS screening methods, the berry spot and acid turbidity tests, cause a high incidence of false-negative results in sanfilippo and morquio syndromes. J. Clin. Lab. Anal. 2002, 16, 253-258.

14. Piraud, M.; Maire, I.; Mathieu, M. Pitfalls of screening for Mucopolysaccharidoses by the dimethylmethylene blue test. Clin. Chem. 1993, 39, 163-164. [PubMed]

15. Auray-Blais, C.; Lavoie, P.; Tomatsu, S.; Valayannopoulos, V.; Mitchell, J.J.; Raiman, J.; Beaudoin, M.; Maranda, B.; Clarke, J.T. UPLC-MS/MS detection of disaccharides derived from glycosaminoglycans as biomarkers of Mucopolysaccharidoses. Anal. Chim. Acta. 2016, 936, 139-148. [CrossRef]

16. Auray-Blais, C.; Bhérer, P.; Gagnon, R.; Young, S.P.; Zhang, H.H.; An, Y.; Clarke, J.T.; Millington, D.S. Efficient analysis of urinary glycosaminoglycans by LC-MS/MS in Mucopolysaccharidoses type I, II and VI. Mol. Genet. Metab. 2011, 102, 49-56. [CrossRef]

17. Chuang, C.K.; Lin, H.Y.; Wang, T.J.; Tsai, C.C.; Liu, H.L.; Lin, S.P. A modified liquid chromatography/tandem mass spectrometry method for predominant disaccharide units of urinary glycosaminoglycans in patients with Mucopolysaccharidoses. Orphanet. J. Rare Dis. 2014, 9, 135. [CrossRef]

18. Lin, H.Y.; Lo, Y.T.; Wang, T.J.; Huang, S.F.; Tu, R.Y.; Chen, T.L.; Lin, S.P.; Chuang, C.K. Normalization of glycosaminoglycan-derived disaccharides detected by tandem mass spectrometry assay for the diagnosis of Mucopolysaccharidosis. Sci. Rep. 2019, 9, 10755. [CrossRef]

19. Wraith, J.E.; Clarke, L.A.; Beck, M.; Kolodny, E.H.; Pastores, G.M.; Muenzer, J.; Rapoport, D.M.; Berger, K.I.; Swiedler, S.J.; Kakkis, E.D.; et al. Enzyme replacement therapy for Mucopolysaccharidosis I: A randomized, double-blinded, placebo-controlled, multinational study of recombinant human alpha-L-iduronidase (laronidase). J. Pediatr. 2004, 144, 581-588. [CrossRef]

20. Lin, H.Y.; Lin, S.P.; Chuang, C.K.; Chen, M.R.; Chen, B.F.; Wraith, J.E. Mucopolysaccharidosis I under enzyme replacement therapy with laronidase-A mortality case with autopsy report. J. Inherit. Metab. Dis. 2005, 28, 1146-1148. [CrossRef]

21. Lin, H.Y.; Lee, C.L.; Chuang, C.K.; Lin, S.P. Long-Term Outcomes of Enzyme Replacement Therapy for Taiwanese Patients with Mucopolysaccharidosis I. Pediatr. Neonatol. 2019, 29. [CrossRef]

22. Muenzer, J.; Wraith, J.E.; Beck, M.; Giugliani, R.; Harmatz, P.; Eng, C.M.; Vellodi, A.; Martin, R.; Ramaswami, U.; Gucsavas-Calikoglu, M.; et al. A phase II/III clinical study of enzyme replacement therapy with idursulfase in Mucopolysaccharidosis II (Hunter syndrome). Genet. Med. 2006, 8, 465-473. [CrossRef] [PubMed]

23. Hendriksz, C.J.; Parini, R.; AlSayed, M.D.; Raiman, J.; Giugliani, R.; Solano Villarreal, M.L.; Mitchell, J.J.; Burton, B.K.; Guelbert, N.; Stewart, F.; et al. Long-term endurance and safety of elosulfase alfa enzyme replacement therapy in patients with Morquio A syndrome. Mol. Genet. Metab 2016, 119, 131-143. [CrossRef] [PubMed]

24. Lin, H.Y.; Chuang, C.K.; Ke, Y.Y.; Hsu, C.C.; Chiu, P.C.; Niu, D.M. Long-term Effects of Enzyme Replacement Therapy for Taiwanese Patients with Mucopolysaccharidosis IVA. Pediatr. Neonatol. 2019, 60, 342-343. [CrossRef] [PubMed] 
25. Harmatz, P.; Giugliani, R.; Schwartz, I.V.; Guffon, N.; Teles, E.L.; Miranda, M.C.; Wraith, J.E.; Beck, M.; Arash, L.; Scarpa, M.; et al. Long-term follow-up of endurance and safety outcomes during enzyme replacement therapy for Mucopolysaccharidosis VI: Final results of three clinical studies of recombinant human N-acetylgalactosamine 4-sulfatase. Mol. Genet. Metab. 2008, 94, 469-475. [CrossRef] [PubMed]

26. Lin, H.Y.; Chen, M.R.; Chuang, C.K.; Chen, C.P.; Lin, D.S.; Chien, Y.H.; Ke, Y.Y.; Tsai, F.J.; Pan, H.P.; Lin, S.J.; et al. Enzyme replacement therapy for Mucopolysaccharidosis VI-experience in Taiwan. J. Inherit. Metab. Dis. 2010, 33, S421-S427. [CrossRef]

27. Lin, H.Y.; Chuang, C.K.; Wang, C.H.; Chien, Y.H.; Wang, Y.M.; Tsai, F.J.; Chou, Y.Y.; Lin, S.J.; Pan, H.P.; Niu, D.M.; et al. Long-term galsulfase enzyme replacement therapy in Taiwanese Mucopolysaccharidosis VI patients: A case series. Mol. Genet. Metab. Rep. 2016, 7, 63-69. [CrossRef] [PubMed]

28. Harmatz, P.; Whitley, C.B.; Wang, R.Y.; Bauer, M.; Song, W.; Haller, C.; Kakkis, E. A novel Blind Start study design to investigate vestronidase alfa for Mucopolysaccharidosis VII, an ultra-rare genetic disease. Mol. Genet. Metab. 2018, 123, 488-494. [CrossRef]

29. Aldenhoven, M.; Jones, S.A.; Bonney, D.; Borrill, R.E.; Coussons, M.; Mercer, J.; Bierings, M.B.; Versluys, B.; van Hasselt, P.M.; Wijburg, F.A.; et al. Hematopoietic cell transplantation for Mucopolysaccharidosis patients is safe and effective: Results after implementation of international guidelines. Biol. Blood Marrow Transplant. 2015, 21, 1106-1109. [CrossRef]

30. Giugliani, R.; Federhen, A.; Vairo, F.; Vanzella, C.; Pasqualim, G.; da Silva, L.M.; Giugliani, L.; de Boer, A.P.; de Souza, C.F.; Matte, U.; et al. Emerging drugs for the treatment of Mucopolysaccharidoses. Expert Opin. Emerg. Drugs 2016, 21, 9-26. [CrossRef]

31. Sawamoto, K.; Stapleton, M.; Alméciga-Díaz, C.J.; Espejo-Mojica, A.J.; Losada, J.C.; Suarez, D.A.; Tomatsu, S. Therapeutic Options for Mucopolysaccharidoses: Current and Emerging Treatments. Drugs 2019, 79, 1103-1134. [CrossRef]

32. Al-Sannaa, N.A.; Bay, L.; Barbouth, D.S.; Benhayoun, Y.; Goizet, C.; Guelbert, N.; Jones, S.A.; Kyosen, S.O.; Martins, A.M.; Phornphutkul, C.; et al. Early treatment with laronidase improves clinical outcomes in patients with attenuated MPS I: A retrospective case series analysis of nine sibships. Orphanet. J. Rare Dis. 2015, 10, 131. [CrossRef] [PubMed]

33. Franco, J.F.; Soares, D.C.; Torres, L.C.; Leal, G.N.; Cunha, M.T.; Honjo, R.S.; Bertola, D.R.; Kim, C.A. Short Communication Impact of early enzyme-replacement therapy for Mucopolysaccharidosis VI: Results of a long-term follow-up of Brazilian siblings. Genet. Mol. Res. 2016, 15. [CrossRef] [PubMed]

34. Furujo, M.; Kosuga, M.; Okuyama, T. Enzyme replacement therapy attenuates disease progression in two Japanese siblings with Mucopolysaccharidosis type VI: 10-Year follow up. Mol. Genet. Metab. Rep. 2017, 13, 69-75. [CrossRef] [PubMed]

35. Clarke, L.; Ellaway, C.; Foster, H.E.; Giugliani, R.; Goizet, C.; Goring, S.; Hawley, S.; Jurecki, E.; Khan, Z.; Lampe, C.; et al. Understanding the Early Presentation of Mucopolysaccharidoses Disorders: Results of a Systematic Literature Review and Physician Survey. J. Inborn Errors Metab. Screen. 2018, 7, 1-12. [CrossRef]

36. Bruni, S.; Lavery, C.; Broomfield, A. The diagnostic journey of patients with Mucopolysaccharidosis I: A real-world survey of patient and physician experiences. Mol. Genet. Metab. Rep. 2016, 8, 67-73. [CrossRef]

37. Kuiper, G.A.; Meijer, O.L.M.; Langereis, E.J.; Wijburg, F.A. Failure to shorten the diagnostic delay in two ultra-orphan diseases (Mucopolysaccharidosis types I and III): Potential causes and implications. Orphanet. J. Rare Dis 2018, 13, 2. [CrossRef]

38. Lin, H.Y.; Lo, C.I.; Chuang, C.K.; Lin, S.P. Mucopolysaccharidosis I (Scheie syndrome)—A rare cause of severe aortic stenosis in a 31-year-old man. J. Formos Med. Assoc. 2015, 114, 1015-1016. [CrossRef]

39. Lin, H.Y.; Chuang, C.K.; Chang, J.H.; Lin, S.P. Early Diagnosis for Mucopolysaccharidosis I-A 6-month-old Female Infant Presenting with Gibbus, Hirsutism and Mongolian Spots in a Well Baby. Clinic. J. Mucopolysacch Rare Dis 2016, 2, 23-26. [CrossRef]

40. Lin, H.Y.; Chuang, C.K.; Lee, K.S.; Lin, S.P. Awareness of Mucopolysaccharidosis in an otorhinolaryngologic clinic. Pediatr. Neonatol. 2017, 58, 198-199. [CrossRef]

41. Lin, H.Y.; Chuang, C.K.; Liu, S.C.; Lin, S.P. Awareness of attenuated Mucopolysaccharidoses in a pediatric orthopedic clinic. Pediatr. Neonatol. 2019, 60, 100-101. [CrossRef]

42. De Jong, J.G.; Wevers, R.A.; Laarakkers, C.; Poorthuis, B.J. Dimethylmethylene blue-based spectrophotometry of glycosaminoglycans in untreated urine: A rapid screening procedure for Mucopolysaccharidoses. Clin. Chem. 1989, 35, 1472-1477. [PubMed] 
43. De Jong, J.G.; Heijs, W.M.; Wevers, R.A. Mucopolysaccharidoses screening: Dimethylmethylene blue versus alcian blue. Ann. Clin. Biochem. 1994, 31 (Pt 3), 267-271. [CrossRef]

44. Hopwood, J.J.; Harrison, J.R. High-resolution electrophoresis of urinary glycosaminoglycans: An improved screening test for the mucopolysaccharidoses. Anal. Biochem. 1982, 119, 120-127. [CrossRef]

45. Zhang, H.; Young, S.P.; Auray-Blais, C.; Orchard, P.J.; Tolar, J.; Millington, D.S. Analysis of glycosaminoglycans in cerebrospinal fluid from patients with Mucopolysaccharidoses by isotope-dilution ultra-performance liquid chromatography-tandem mass spectrometry. Clin. Chem. 2011, 57, 1005-1012. [CrossRef]

46. Oguma, T.; Tomatsu, S.; Montano, A.M.; Okazaki, O. Analytical method for the determination of disaccharides derived from keratan, heparan, and dermatan sulfates in human serum and plasma by high-performance liquid chromatography/turbo ionspray ionization tandem mass spectrometry. Anal. Biochem. 2007, 368, 79-86. [CrossRef] [PubMed]

47. Khan, S.A.; Mason, R.W.; Giugliani, R.; Orii, K.; Fukao, T.; Suzuki, Y.; Yamaguchi, S.; Kobayashi, H.; Orii, T.; Tomatsu, S. Glycosaminoglycans analysis in blood and urine of patients with Mucopolysaccharidosis. Mol. Genet. Metab. 2018, 125, 44-52. [CrossRef] [PubMed]

48. Chuang, C.K.; Lin, H.Y.; Lin, S.P. Keratanase II digestion accompanied with a liquid chromatography/tandem mass spectrometry for urinary keratan sulfate quantitative analysis. J. Mucopolysacch. Rare Dis. 2017, 3, 20-27.

49. Shimada, T.; Tomatsu, S.; Mason, R.W.; Yasuda, E.; Mackenzie, W.G.; Hossain, J.; Shibata, Y.; Montaño, A.M.; Kubaski, F.; Giugliani, R.; et al. Di-sulfated Keratan Sulfate as a Novel Biomarker for Mucopolysaccharidosis II, IVA, and IVB. JIMD Rep. 2015, 21, 1-13.

50. Hopwood, J.J.; Muller, V.; Smithson, A.; Baggett, N. A fluorometric assay using 4-methylumbelliferyl alpha-L-iduronide for the estimation of alpha-L-iduronidase activity and the detection of Hurler and Scheie syndromes. Clin. Chim. Acta 1979, 92, 257-265. [CrossRef]

51. Chuang, C.K.; Lin, H.Y.; Wang, T.J.; Huang, Y.H.; Chan, M.J.; Liao, H.C.; Lo, Y.T.; Wang, L.Y.; Tu, R.Y.; Fang, Y.Y.; et al. Status of newborn screening and follow up investigations for Mucopolysaccharidoses I and II in Taiwan. Orphanet. J. Rare Dis. 2018, 13, 84. [CrossRef]

52. Voznyi, Y.V.; Keulemans, J.L.; van Diggelen, O.P. A fluorimetric enzyme assay for the diagnosis of MPS II (Hunter disease). J. Inherit. Metab. Dis. 2001, 24, 675-680. [CrossRef] [PubMed]

53. Barone, R.; Nigro, F.; Triulzi, F.; Musumeci, S.; Fiumara, A.; Pavone, L. Clinical and neuroradiological follow-up in Mucopolysaccharidosis type III (Sanfilippo syndrome). Neuropediatrics 1999, 30, $270-274$. [CrossRef] [PubMed]

54. Yuen, M.; Fensom, A.H. Diagnosis of classical Morquio's disease: N-acetylgalactosamine 6-sulphate sulphatase activity in cultured fibroblasts, leukocytes, amniotic cells and chorionic villi. J. Inherit. Metab. Dis. 1985, 8, 80-86. [CrossRef] [PubMed]

55. Brooks, D.A.; McCourt, P.A.; Gibson, G.J.; Ashton, L.J.; Shutter, M.; Hopwood, J.J. Analysis of $\mathrm{N}$-acetylgalactosamine-4-sulfatase protein and kinetics in Mucopolysaccharidosis type VI patients. Am. J. Hum. Genet. 1991, 48, 710-719.

56. Lin, H.Y.; Lee, C.L.; Lo, Y.T.; Wang, T.J.; Huang, S.F.; Chen, T.L.; Wang, Y.S.; Niu, D.M.; Chuang, C.K.; Lin, S.P. The Relationships Between Urinary Glycosaminoglycan Levels and Phenotypes of Mucopolysaccharidoses. Mol. Genet. Genomic Med. 2018, 6, 982-992. [CrossRef]

57. Colón, C.; Alvarez, J.V.; Castaño, C.; Gutierrez-Solana, L.G.; Marquez, A.M.; O’Callaghan, M.; Sánchez-Valverde, F.; Yeste, C.; Couce, M.L. A selective screening program for the early detection of mucopolysaccharidosis: Results of the FIND project-A 2-year follow-up study. Medicine 2017, 96, e6887. [CrossRef]

58. Erickson, R.P.; Sandman, R.; Epstein, C.J. Lack of relationship between blood and urine levels of glycosaminoglycans and lysomal enzymes. Biochem Med. 1975, 12, 331-339. [CrossRef]

59. Saville, J.T.; McDermott, B.K.; Fuller, M. Glycosaminoglycan fragments as a measure of disease burden in the Mucopolysaccharidosis type I mouse. Mol. Genet. Metab. 2018, 123, 112-117. [CrossRef]

60. Fujitsuka, H.; Sawamoto, K.; Peracha, H.; Mason, R.W.; Mackenzie, W.; Kobayashi, H.; Yamaguchi, S.; Suzuki, Y.; Orii, K.; Orii, T.; et al. Biomarkers in patients with mucopolysaccharidosis type II and IV. Mol. Genet. Metab. Rep. 2019, 19, 100455. [CrossRef]

61. Lin, H.Y.; Chuang, C.K.; Chen, M.R.; Lin, S.J.; Chiu, P.C.; Niu, D.M.; Tsai, F.J.; Hwu, W.L.; Chien, Y.H.; Lin, J.L.; et al. Clinical characteristics and surgical history of Taiwanese patients with mucopolysaccharidosis type II: Data from the Hunter Outcome Survey (HOS). Orphanet. J. Rare Dis. 2018, 13, 89. [CrossRef] 
62. Lin, H.Y.; Chuang, C.K.; Lee, C.L.; Tu, R.Y.; Lo, Y.T.; Chiu, P.C.; Niu, D.M.; Fang, Y.Y.; Chen, T.L.; Tsai, F.J.; et al. Mucopolysaccharidosis III in Taiwan: Natural History, Clinical and Molecular Characteristics of 28 Patients Diagnosed During a 21-year Period. Am. J. Med. Genet. A 2018, 176A, 1799-1809. [CrossRef] [PubMed]

63. Lin, H.Y.; Chuang, C.K.; Chen, M.R.; Chiu, P.C.; Ke, Y.Y.; Niu, D.M.; Tsai, F.J.; Hwu, W.L.; Lin, J.L.; Lin, S.P. Natural history and clinical assessment of Taiwanese patients with Mucopolysaccharidosis IVA. Orphanet, J. Rare Dis. 2014, 9, 21. [CrossRef] [PubMed]

64. Arn, P.; Wraith, J.E.; Underhill, L. Characterization of surgical procedures in patients with Mucopolysaccharidosis type I: Findings from the MPS I Registry. J. Pediatr. 2009, 154, 859-864.e3. [CrossRef] [PubMed]

65. Mendelsohn, N.J.; Harmatz, P.; Bodamer, O.; Burton, B.K.; Giugliani, R.; Jones, S.A.; Lampe, C.; Malm, G.; Steiner, R.D.; Parini, R.; et al. Importance of surgical history in diagnosing mucopolysaccharidosis type II (Hunter syndrome): Data from the Hunter Outcome Survey. Genet. Med. 2010, 12, 816-822. [CrossRef] [PubMed]

66. Tomatsu, S.; Okamura, K.; Maeda, H.; Taketani, T.; Castrillon, S.V.; Gutierrez, M.A.; Nishioka, T.; Fachel, A.A.; Orii, K.O.; Grubb, J.H.; et al. Keratan sulphate levels in mucopolysaccharidoses and mucolipidoses. J. Inherit. Metab. Dis. 2005, 28, 187-202. [CrossRef]

67. Komosińska-Vassev, K.; Olczyk, K.; Koźma, E.M.; Olczyk, P.; Wisowski, G.; Winsz-Szczotka, K. Alterations of glycosaminoglycan metabolism in the development of diabetic complications in relation to metabolic control. Clin. Chem. Lab. Med. 2005, 43, 924-929. [CrossRef]

68. Lin, S.P.; Lin, H.Y.; Wang, T.J.; Chang, C.Y.; Lin, C.H.; Huang, S.F.; Tsai, C.C.; Liu, H.L.; Keutzer, J.; Chuang, C.K. A Pilot Newborn Screening Program for Mucopolysaccharidosis Type I in Taiwan. Orphanet. J. Rare Dis. 2013, 8, 147. [CrossRef]

69. Chan, M.J.; Liao, H.C.; Gelb, M.H.; Chuang, C.K.; Liu, M.Y.; Chen, H.J.; Kao, S.M.; Lin, H.Y.; Huang, Y.H.; Kumar, A.B.; et al. Taiwan National Newborn Screening Program by Tandem Mass Spectrometry for Mucopolysaccharidoses Types, I., II, and VI. J. Pediatr. 2019, 205, 176-182. [CrossRef]

(C) 2019 by the authors. Licensee MDPI, Basel, Switzerland. This article is an open access article distributed under the terms and conditions of the Creative Commons Attribution (CC BY) license (http://creativecommons.org/licenses/by/4.0/). 